\title{
Application of a Real-Time Dashboard to Reduce Ventilator-Associated Pneumonia in Intensive Care Units
}

\author{
Mohammad Fathi ${ }^{1}$, Hamid Moghaddasi ${ }^{2 *}$, Forough Rahimi ${ }^{3}$ and Monir Ebrahimi Aghdam ${ }^{3}$ \\ ${ }^{1}$ Department of Anesthesiology, Faculty of Medicine, Shahid Beheshti University of Medical Sciences, Iran \\ ${ }^{2}$ Department of Health Information Technology and Management, Faculty of Paramedical Sciences, Shahid Beheshti University of Medical Sciences, \\ Iran \\ ${ }^{3}$ Faculty of Paramedical Sciences, Shahid Behshti University of Medical Sciences, Iran
}

Submission: January 15, 2017; Published: February 28, 2017

*Corresponding author: Hamid Moghaddasi, Associate Professor of Health Information Management \& Medical Informatics, Faculty of Paramedical Sciences, ShahidBeheshti University of Medical Sciences, Tehran, Iran, Email: moghaddasi@sbmu.ac.ir

\begin{abstract}
Introduction and Purpose: Ventilator-associated pneumonia is the second most common nosocomial infection that develops in patients admitted to the intensive care unit. The mortality rate for VAP ranges from $24 \%$ to $76 \%$ and is even higher than the primary illness. Based on the importance of this issue, many organizations have focused on strategies and guidelines to reduce the occurrence of complications such as ventilator associated pneumonia. Despite these guidelines, due to multi orders with different conditions and time periods, multi caregivers in the intensive care unit and human mistakes, still there are high rates of VAP. The purpose of this study is to provide an overview of real-time dashboards applications which were designed and implemented as a solution to reduce Ventilator-associated-pneumonia in Intensive Care Unit.
\end{abstract}

Background: The VAP reduction dashboards in different research studies are implemented with real-time and visual data display features which help caregivers to know the existing condition. So they can do the necessary tasks. Besides, alerts and reminders are among the effective features of this software.

Findings: Because of the representing order lists and the way tasks are done, VAP reduction dashboards, will reduce human mistakes regarding the time consumed and the way it is done. Also, representing history of finished tasks prevents mistakes caused by coordination between multiple caregivers, and finally clinicians begin to understand the importance of consistency in the clinical documentation templates and practices.

Conclusion: Finally, using mobile or web based version, connecting dashboard to patient medical record, representing management information, using sensor and hardware for data entry and connecting dashboard to decision support system make VAP reduction dashboards more effective.

Keywords: Ventilator-associated pneumonia; VAP dashboard; Intensive Care Unit

Abbreviations: CDC: Centers for Disease Control and Prevention; CPOE: Computerized Provider Order Entry; EMR: Electronic Medical Record; HAIs: Hospital-Acquired Infections; ICU Intensive Care Unit; INICC: International Consortium Controlling Hospital Infections; LOS: Lengths of Stays; MDR: Multi-Drug-Resistant; VAP: Ventilator-Associated Pneumonia

\section{Introduction}

Ventilator-associated pneumonia is the second most common nosocomial infection that develops in patients admitted to the intensive care unit.VAP is the most common nosocomial infection in the ICU [1,2]. Ventilator-associated pneumonia is the second most common nosocomial infection which contains $86 \%$ of nosocomial pneumonia [3]. Furthermore, VAP is usually acquired in hospital settings approximately 48-72 hours after mechanical ventilation.VAP occurs in patients who are ventilated either by an endotracheal tube or tracheostomy $[4,5]$. It is worth mentioning that the mortality rate associated with VAP ranges from 24 to $76 \%$, and is even higher among critically ill patients $[5,6]$. In addition to the increased risk of death, the disease causes increase ICU lengths of stays (LOS) from 4to 13days [3]. It also increases the hospital costs and the need for extra hospital care procedures indirectly [1]. 


\section{International Journal of Pulmonary \& Respiratory Sciences}

According to the published report in 2014 by the International Consortium Controlling Hospital Infections (INICC), the overall rate of ventilator-associated pneumonia was also higher (16.8 per 1000 days using a ventilator). Using such an index to measure the risk is due to the fact that if patients use a ventilator more than two days, they will suffer from VAP [1].

VAP is categorized into two kinds of early-onset VAP and late-onset VAP. Early-onset VAP occurs during the first four days of mechanical ventilationand is usually caused by antibiotic sensitive bacteria. Late-onset VAP develops five or more days after the initiation of mechanical ventilation and is caused by multidrug-resistant (MDR) pathogens [4,5].

The main causes of VAP include: bacterial colonization of the aero digestive tract and aspiration of contaminated oral secretions into the lower airways because endotracheal tubes used to ventilate neonates which are not cuffed [4]. The major causes of acquiring endemic VAP is oropharyngeal colonization by the endogenous flora or by pathogens acquired exogenously from the intensive care unit environment, especially the hands or apparel of health-care workers, contaminated respiratory equipment, hospital water or air. The stomach represents a potential site of secondary colonization and reservoir of nosocomial Gram-negative bacilli. Absorption of microbe-laden oropharyngeal, gastric or tracheal secretions around the cuffed endotracheal tube into the normally sterile lower respiratory tract results in most cases of endemic VAP $[1,7,8]$.

In order to control and reduce the incidence of VAP, numerous institutions have attempted to give medical guidelines. The United States Centers for Disease Control and Prevention (CDC) has also published a guide entitled "A Guide to prevent nosocomial pneumonia" in 2003. Some of the guidelines for the prevention of VAP are listed in the mentioned guide include: The angle of the head of the bed, the cuff pressure inside the tracheal tube, the ventilator circuit changes, oral care (including brushing teeth, using Chlorhexidine, applying water soluble mouth moisturizer), rotating the position of oral endotracheal tube, sedation reduction, consuming stress ulcer prophylaxis drugs, consuming venous thrombo embolism Prophylaxis drugs, suctioning contaminated secretions, evaluating the patient's readiness daily to wean them off the ventilator, using and changing antibacterial filter, and heat and moisture exchangers [9].

The guidelines are used as a combination of a number of guidelines in the intensive care unit, and the results have been effective in reducing the incidence of VAP. Despite such guidelines, the rate of the incidence of VAP is still significant. On the one hand, the number of different guidelines and implementation of each of them in different hours and conditions, and human error in remembering responsibilities increase the probability of not implementing the guidelines correctly and timely. On the other hand, due to the constant shifts of the staff in the intensive care unit, and lack of coordination between staff and not informing each other of carrying out the guidelines and the time of their implementation, the incidence of ventilator-associated pneumonia is inevitable [10].

Some of the possible errors include: notchangingthe ventilator circuit and antibacterial filter timely, ignoring the guidelines for cleaning patients' mouth, and not adjusting the angle of the head of the bed.

One of the strategies to reduce human errors and create coordinationamong thestaff in order to perform accurate and timely guidelines is the use of informatics tools such as dashboard software, reminders and alarms. The purpose of this study was to use dashboard software to reduce ventilatorassociated pneumonia.

This study was conducted through a library method and searching the databases of PubMed, Science Direct, Google Scholar and the key words of dashboard, ventilator associated pneumonia, VAP reduction dashboard, VAP dashboard, pneumonia, alert, ICU, ventilator and monitoring software. A total number of 58 articles were available. After investigating the quality of the articles based on the references and conforming their objectives with the present study, 23 articles published from 2003 to 2014 were chosen.

The present study first identified different kinds of dashboards in the field of health and the studies providing dashboards to prevent ventilator-associated pneumonia in the ICU were studied in terms of the design, sample, intervention, prominent features of the dashboard software of the studies, the results of the application of dashboard and its impacts to reduce ventilator-associated pneumonia.

\section{Background}

Increasingly the healthcare organizations define dashboard software as a means to measure and improve care quality. Dashboard software allows easy access to various databasesin a single display format [11]. The superiority of the display format of the data to their numerical format and providing real-time information are the most important features distinguishing between dashboard software and decision support systems in the field of health.In such applications, the data related to the patients, health care professionals and equipment in the field of healthcare used [12].

Dashboard applications in the field of health are used in the two forms of "Quality dashboard" and "Clinical dashboard". Quality dashboard is a visual display of the quality indices that allows managers to identify areas needing improvement [13]. For example, in England quality dashboard is established by the Ministry of Health to evaluate the performance of health care providers including the ratio of the nurses to the beds for patients, the ratio of physicians to the number of beds, the results of the staff audit and patients and the incidence of nosocomial infections and mortality rate [14]. Ultimately, the information is used by senior authorities to decide on the quality and output of health service providers [13]. 
Clinical dashboard applications are used with the aim of providing practical and timely information in order to create the right conditions to decide on the daily performance of health staff improving the quality of care for the patients [13]. Such tools help the health care staff to do and record the procedures of medical guidelines and protocols in detail and when it is required [10].

The ICU is also one of the subordinate vital health areas of the users of dashboard applications in a way that the processes of the ICU done by service providers and the management of its resources can be efficiently managed through dashboard application. For example, beds in the ICUare considered as one of the crucial sources of the hospital. Thus, the following problems occur: the timely rejection of or early discharge of the current ICU patients to accept new emergency patients.In order to reduce such problems, it is so helpful to monitor and managethe beds through dashboard in a network of municipal and provincial hospitals [15].

The dashboard software for the prevention of ventilatorassociated pneumonia is also one of the varieties of dashboard applications used in ICU. The application provides a real-time and graphic display of the information (a combination of text and image) so that the ICU staff can be informed of the existing condition with a glance and take the necessary measures. In addition to mentioned items, reminders and alarmsin due time of the guidelines are effective features of the application.

Numerous studies have been conducted to evaluate the application of dashboard and its effectiveness to prevent ventilator-associated pneumonia which has been dealt with in the following paragraphs.

A Real-time ventilator management dashboard: "Toward Hardwiring Compliance with Evidence-based Guidelines" is the title of a study done by Starmer, et al. [10] in 2007. In this study, a ventilator management dashboard application is designed to display the patient's condition by using the guidelines provided by the Center for Disease Control and Prevention such as the prevention of DVT Prophylaxis, stress ulcer prophylaxis, sedation management and daily assessment of readiness to exudate, adjusting the head of the bed at the angle of 35-450, brushing the teeth and hypo pharyngeal suctioning. Each guideline based on its nature is done by several employees of the ICU at different times. Therefore, the dashboard application coordinates the individuals and also shows proper colors for the status of doing the guidelines. The dashboard utilizes data from various sourcesystems already in use by clinical personnel, including clinical documentation systems and computerized provider order entry (CPOE). These systems pass results through an interface engine which in turn routes the results to subscriber systems. The system also provides the possibility of reporting based on the individuals and processes. By September 2007, dashboard software was installed on all adult intensive care units which increased the number of procedures [10].
"Implementation of a Real-time Compliance Dashboard to Help Reduce SICU Ventilator-Associated Pneumonia with the Ventilator Bundle" is the title of the study by Zaydfudim, et al. [16] through the dashboard application in a previous study in 2009. During the study, guidelines for the prevention of VAP improved from $39 \%$ in 2007 to $89 \%$ in 2008 . In addition, the incidence of VAP reduced by 39 percent from 15.2 to 9.3 cases per 1,000 days using a ventilator in the intensive care unit [16].

"Real-Time, Right Care" is the title of a study carried out by Debra, et al. [17] in 2013 with the support of Health East institution and provision of dashboard application to manage guidelines for the prevention of VAP. The Ventilator-Associated Pneumonia (VAP) Quality Monitor is a software tool that monitors clinical transactions as they occur within Health East's electronic medical record (EMR) system and uses embedded logic to evaluate the transactions against pre-defined processes of care related to preventing VAP. The information is constantly available via a wall-mounted monitor, or it can be displayed on demand at any user's desktop.

For instance, nurses may take a quick glance at the monitor and see status. Such immediate feedback helps the nurses to take measures when necessary. The guidelines of adjusting the head of the bed, daily sedation vacations and the assessment of readiness to exudate, consuming anticoagulants and drugs preventing peptic ulcer disease prophylaxis, venous thrombosis prophylaxis, daily oral care with Chlorhexidine were considered in this study. In the year prior to the pilot project, the pilot ICU had 3.07 cases of VAP per 1,000 ventilators. In the year after the onset of the project, there were 0 cases of VAP [17].

"Infection Control for Critically Ill Trauma Patients" is the title of a study by Heather in 2012, conducted through describing a comprehensive multi-disciplinary approach for VAP focused on prevention, diagnosis and appropriate management. For the trauma surgical population, VAP continues to be one of the most challenging hospital-acquired infections (HAIs), with the incidence rate of the highest in the burn (7.4 cases per 1000 days using a ventilator), trauma (6.5 cases per 1000 days using a ventilator), and neurosurgical (3.8 cases per 1000 days using a ventilator) intensive care units (ICUs) compared with an overall pooled mean rate of 2.2 cases per 1000 days using a ventilator.

Regarding the issue that the prevention of VAP requires coordinated efforts between providers, nursing staff and respiratory therapists, in this study, the elements of adjusting the head of bed at more than $30^{\circ}$, a daily sedation awakening trial and the assessment of readiness to exudate, oral care with Chlorhexidine, peptic ulcer disease prophylaxis and deep vein thrombosis prophylaxis were considered. The quality dashboard application is accessible through the electronic medical record of the patient and the status of doing the guidelines is shown on monitors mounted throughout the ICUs. The result of the study indicates a $63 \%$ reduction in the absolute number of VAP cases and also a reduction in the treatment period from 12 days to 
10days during the 4 years of using the dashboard application [18].

Two more studies on the clinical dashboard applications of the ICU processes are provided: "Clinical Dashboards: Impact on Workflow, Care Quality, and Patient Safety" is the title of a study performed by Egan, the researcher of Massachusetts General Hospital in 2006.In the same year, Massachusetts General Hospital used the dashboard application in the operating room in order to monitor and display essential dataof the patients automatically on the screen. Moreover, the application receives processes, integrates, and shows a wide range of the data of patients on the screen. During the study, the mentioned idea of using the dashboard application was extended to the ICU. According to Egan there are not only many similarities between the workflow of the ICU and the workflow of operating room, but also more complexities in many cases; therefore, providing dashboard management application is required for the ICU.

The following features are considered for the proposed application:

Making a coordination among the health care team, data management of the patient such as allergies, daily status of the patient, medical history, medication regimen, the dose of injections, the results of tests, prescribed treatment plan, adjusting devices such as a ventilator and displaying the data depending on the user (doctor, nurse and anesthesiologist) [19].

"Designing and evaluatingan electronic application of nursing process: a step to improve learning and nursing care" is the title of a study conducted by Mazloum, et al. [20] in Mashhad in 1393. Mazloum has expressed the reason of performing the study was thatthere is a need for the nursing field to use an electronic application of nursing process-mail software to use the nursing process and expressed the mismatch between external applications but the available foreign applications are not suitable for the country in terms of language, cultural and social factors and clinical conditions. The study was conducted in two parts: designing and evaluating the application.The first part of the study was carried out in the four stages of "developing nursing process in accordance with the application", "designing algorithm", "test run" and "final reform". The second part is also done with the participation of 20 students and nurses in the ICU at Ghaem Hospital of Mashhad. They did the nursing processes through the designed application for 3 patients and their views have been collected by the questionnaire of application evaluation.

The application includes the menus of reference information, recording background information of the patient, recording the nursing process, setting, alerts and the guide. The results of the evaluation show that $81.3 \%$ of the research units evaluated the application as good or very good generally. The most important advantage of the application according to $90 \%$ of the nurses is the accuracy of the electronic information compared with the handwritten form helping to organize the problems of the patients. According to $100 \%$ of the students, the most important advantages of the application are its simplicity, helping the division of responsibility, evaluating the warning signs and preventing errors; therefore, it is possible to design a native application for nursing processes in accordance with the health care system with which the nurses and students are satisfied. Moreover, the implementation of such an application helps to increase the accuracy and reduce the errors and division of responsibility. Such factors improve the patient care [20]. The summary of the conducted studies is provided in Table 1.

\section{Findings}

This study was conducted to investigate the effect of the dashboard application to reduce ventilator-associated Pneumonia. Four investigated studies are completely in line with the objective of the present study and two studies provide a dashboard application to do the ICU processes.The uses of the dashboard application based on theconducted studies in this study suggest that the use of the dashboard application can help toremove the factors causing VAP in ICU.

Failing to remember the guidelines and doing them properly due can cause the colonization of bacteria in the oral mucosa and tracheal secretions and aspiration to the lower part of the pharynx of the patient due to the large number of guidelinesand thus cause the patient to get VAP. The dashboard application displays a list of guidelines and information, such as the angle of the head of the bed, and the name and dose of drugs to ensure the nursesso that the guidelines are done with the minimum mistake in terms of forgetting the number of times. The change of shifts by the specialists and nurses of the health care unit causes them to be unaware of the status of the guidelines for the prevention of VAP in the previous shift. So, displaying the history and status of the current guidelines on the dashboard application due to its information giving nature helps the nurses and specialist prevent the errors and improves teamwork. However, if there is not such an application, many of the members of the team would deny the responsibility even though they are informed of the status of the guidelines.

Dashboard application uses user accounts and controls the access levels clarifying the mentioned cases. Doing VAP prevention guidelines is not among the responsibility of the nurses to document which increases the human error. Dashboard application makes it possible to record the time of doing the guidelines and provide a suitable environment for documentation which will subsequently lead to doing the guidelines timely and reducing ventilator-associated pneumonia. In addition to the effect of dashboard application on reducing ventilator-associated pneumonia, the continued use of the application and the observation of positive effects make the staff aware of the importance of documentation.

Another outcome of the use of dashboard for the prevention of VAP is to train people in doing the guidelines timely. In fact, emphasizing the reason to do the guidelines and its effect on 
the quality of services provided by the health care staff due to instructions, will pass better training in this regard.

Ultimately, since the focus of the application is on patients, the service providers provide systematic strategies to ensure that all patients receive all the best care; therefore, it reduces ventilator-associated pneumonia.

Table 1: Summary of the conducted studies.

\begin{tabular}{|c|c|c|c|c|c|c|}
\hline Study & Design & Sample & Intervention & control & Results & Distinctive features \\
\hline $\begin{array}{c}\text { Starmer et al. } \\
{[10]}\end{array}$ & $\begin{array}{l}\text { Before and after } \\
\text { the study }\end{array}$ & $\begin{array}{l}\text { not clear } \\
\text { (presumably } \\
\text { the nursing } \\
\text { staff) }\end{array}$ & $\begin{array}{l}\text { Ventilator management } \\
\text { dashboard, presented } \\
\text { as a screensaver } \\
\text { and accessible from } \\
\text { EMR with indicators } \\
\text { for each patient for } \\
\text { each patient for each } \\
\text { element of ventilator } \\
\text { management bundle }\end{array}$ & none & $\begin{array}{l}\text { Increasing compliance with } \\
\text { bundle elements (RASS } \\
\text { score, weaning, Head of Bed } \\
\text { adjustment, OB, oral care). } \\
\text { Nurse Managers and Charge } \\
\text { Nurses note that dashboard } \\
\text { allows them to more } \\
\text { quickly see when a nurse is } \\
\text { overloaded with patient and } \\
\text { can divert resources. }\end{array}$ & $\begin{array}{l}\text { Each indicator has } \\
\text { traffic light status } \\
\text { (green done, yellow } \\
\text { imminent, red } \\
\text { overdue/not done). } \\
\text { Indicators are not } \\
\text { always up to date } \\
\text { as reliant on timely } \\
\text { documentation } \\
\text { - problematic if } \\
\text { workflow uses 'batch' } \\
\text { Documentation }\end{array}$ \\
\hline $\begin{array}{l}\text { Zayfudin et al. } \\
\text { [16] }\end{array}$ & $\begin{array}{c}\text { Interrupted } \\
\text { time series } \\
\text { analysis Pre- } \\
\text { intervention } \\
\text { period January } \\
\text { 2005-june } 2007 \\
\text { (30 Months), } \\
\text { implementation } \\
\text { in July } \\
\text { 222007, post- } \\
\text { intervention } \\
\text { period August } \\
\text { 2007- July 2008 } \\
\text { (12 Months) }\end{array}$ & $\begin{array}{l}\text { Nursing and } \\
\text { medical staff }\end{array}$ & $\begin{array}{l}\text { Ventilator management } \\
\text { dashboard, presented } \\
\text { as a screensaver } \\
\text { with indicators for } \\
\text { each patient for each } \\
\text { element of ventilator } \\
\text { management bundle }\end{array}$ & none & $\begin{array}{c}\text { Average compliance with } \\
\text { ventilator bundle improved } \\
\text { from } 39 \% \text { in August } 2007 \text { to } \\
89 \% \text { in July } 2008(\mathrm{P}<.001) \text {. } \\
\text { Rates of ventilator- associated } \\
\text { pneumonia(VAP) decreased } \\
\text { from a mean(SD) of } 15.2(7.0) \\
\text { to } 9.3(4.9) \text { events per } \\
1000 \text { ventilator days after } \\
\text { introduction of the dashboard } \\
\text { (P = .01). Quarterly VAP rates } \\
\text { were significantly reduced in } \\
\text { the November } 2007 \text { through } \\
\text { January } 2008 \text { and February } \\
\text { through April } 2008 \text { periods } \\
\text { (P <.05). For the August } \\
\text { through October } 2007 \text { and } \\
\text { May through July } 2008 \\
\text { quarters, the observed rate } \\
\text { reduction was not statistically } \\
\text { significant. }\end{array}$ & $\begin{array}{l}\text { Use of color coding } \\
\text { for indicators; green } \\
\text { = incompliance, red } \\
\text { = out of compliance, } \\
\text { yellow = soon due } \\
\text { Managers received } \\
\text { daily reports on } \\
\text { compliance levels }\end{array}$ \\
\hline Debra [17] & $\begin{array}{l}\text { Before and } \\
\text { after the } \\
\text { intervention, } \\
\text { the } \\
\text { implementation } \\
\text { of the project } \\
\text { was conducted } \\
\text { since October } \\
\text { 2009. The time } \\
\text { interval of } \\
\text { before and after } \\
\text { is not clear. }\end{array}$ & $\begin{array}{l}\text { Nursing and } \\
\text { medical staff }\end{array}$ & $\begin{array}{l}\text { Ventilator management } \\
\text { dashboard, presented } \\
\text { as a screen, provided } \\
\text { through an electronic } \\
\text { health record for each } \\
\text { patient as well as } \\
\text { the management of } \\
\text { pre-defined guidelines } \\
\text { relating to the } \\
\text { ventilator. }\end{array}$ & none & $\begin{array}{l}\text { In the year prior to the } \\
\text { pilot project, the pilot ICU } \\
\text { had 3.07cases of VAP per } \\
\text { 1000ventilator.In the year } \\
\text { after the onset of the project, } \\
\text { there were } 0 \text { cases of VAP }\end{array}$ & $\begin{array}{l}\text { an individual nurse } \\
\text { may take a quick } \\
\text { glance at the monitor } \\
\text { and see that one of his } \\
\text { assigned ventilated } \\
\text { patients has a "green" } \\
\text { status for periodic } \\
\text { wean assessment } \\
\text { and therefore does } \\
\text { not need immediate } \\
\text { attention, but another } \\
\text { ventilated patient may } \\
\text { show a "red" status } \\
\text { for daily oral care, } \\
\text { meaning the nurse } \\
\text { needs to complete that } \\
\text { activity.. }\end{array}$ \\
\hline Heather [18] & $\begin{array}{l}\text { Before and } \\
\text { after the } \\
\text { intervention. } \\
\text { The } \\
\text { implementation } \\
\text { of the project } \\
\text { was conducted } \\
\text { since } 2007 \text { to } \\
2010 .\end{array}$ & $\begin{array}{l}\text { Nursing and } \\
\text { medical staff }\end{array}$ & $\begin{array}{l}\text { The quality dashboard } \\
\text { connected to the } \\
\text { medical records of } \\
\text { a patient displaying } \\
\text { the status of doing } \\
\text { the guidelines on the } \\
\text { monitor in the ICU. }\end{array}$ & none & $\begin{array}{l}\text { This had led to a } 63 \% \\
\text { reduction in the number of } \\
\text { VAP cases over the past } 4 \\
\text { years although improving } \\
\text { our management of those } \\
\text { cases that occur through } \\
\text { appropriate antimicrobial } \\
\text { therapy based on local } \\
\text { microbiology. }\end{array}$ & $\begin{array}{c}\text { No cases have been } \\
\text { mentioned. }\end{array}$ \\
\hline
\end{tabular}




\section{International Journal of Pulmonary \& Respiratory Sciences}

\section{Discussion and Conclusion}

Investigating the results of the performance of the dashboard application in studied investigations, it can be said that in the study conducted by Zaydfudim, et al. [16] in 2007, VPA was reduced by 38 percent (from 15.2 to 9.3 cases per 1,000 days of using a ventilator) as reported.In the study carried out by Debra, et al. [17] in 2013, VPA was reduced by 100 percent (from 3.07 to 0 cases) as reported and it seems that it is possible to display the dashboard on the monitor mounted in the ICU at every moment.The long duration of the study, the high number of nurses and its connection to patients' medical records increase the impacts of using dashboard application in reducing ventilator-associated pneumonia. The environment of the study and the work discipline of the mentioned studies were involved in the effectiveness of the use of dashboard application to reduce ventilator-associated pneumonia, since increasing the work discipline in an environment makes it more difficult to change.

Due to the increasing development of IT and the influence of information systems in the field of health andclinical care, adding more features to the dashboard application to provide health services in a better way and focus more on patients. The mobile version of the dashboard application can be used on the nurses' tablets or cell phones and makes it possible to use it immediately beside patients' bed. In such a condition, the time of doing the guidelines is recorded with less time error and also more quickly and easily.

Connecting the dashboard application to patients' medical file allows you to get the information and makes it possible to record the summary of the data of doing the guidelines in the medical file. Providing high-rank managers with the management information of the trend graphs of the incidence of disease makes them aware of the effectiveness of the nursing processes done in the health care units and proper decision making. Since the number of health care nurses is not usually equal to the number of nurses, it is quicker to enter the data into the application through hardware systems such as the use of sensors to check the angle of the head of the bed or data transfer technologies of NFC on the ventilator circuit and heat and moisture exchangers that can be helpful in recording the time of change.

Furthermore, connecting the dashboard application to DSS systems can help to change the number of times the guidelines are practiced and the way to do it based on the condition of patients.

Providing a web-based dashboard application facilitates the access and online use and can be used to improve the application.

Finally, using the dashboard application can reduce the rate of the incidence of different infections and do the management processes in the field of health in a better way. For example, the dashboard applicationcan also be effective in preventing other infections such as catheter-related urinary tract infections, the most common nosocomial infections.

\section{References}

1. Gianluigi Li Bassi, Miquel Ferrer, Joan Daniel Marti, Talitha Comaru, Antoni Torres (2014) Ventilator-Associated Pneumonia. Seminars in Respiratory and Critical Care Medicine 35(4): 469.

2. NasiaSafdar, Christopher J Crnich, Dennis G Maki MD (2005) The Pathogenesis of Ventilator-Associated Pneumonia: Its Relevance to Developing Effective Strategies for Prevention. Respir Care 50(6): 725739.

3. Steven M, Koenig, Jonathon D, Truwit (2006) Ventilator-Associated Pneumonia: Diagnosis, Treatment, and Prevention. Clin Microbiol Rev 19(4): 637-657.

4. Ahmed A Khattab, Dalia M El-Lahony, Wessam F Soliman (2014) Ventilator-associated pneumonia in the neonatal intensive care unit. Menoufiya medical journal 27(1): 73-77.

5. Pravin Charles MV, Arunava Kali, Joshy M Easow, Noyal Maria Joseph, Ravishankar M, et al. (2014) Ventilator-associated pneumonia. Australas Med J 7(8): 334-344.

6. Jean Chastre, Jean-Yves Fagon (2002) Ventilator-associated pneumonia. Am J Resp Crit Care Med 165(7): 867-903.

7. Hamid Reza Ebrahimi Fakhar, Korosh Rezaie, Hamid Reza kohestani (2010) Effect of closed endotracheal suction on incidence of ventilatorassociated pneumonia. Scientific Journal of Kurdistan University of Medical Sciences 15(2): 79-87.

8. Dan L Longo, Anthony S Fauci, Dennis L Kasper, Stephen L Hauser, Larry Jameson J, et al. (2012) Harrison\'s Principles of Internal Medicine $\left(16^{\text {th }}\right.$ edn). The McGraw-Hill Companies, USA.

9. Ofelia C Tablan, Larry J Anderson, Richard Besser, Carolyn Bridges, Rana Hajjeh (2003) Guidelines For Preventing Health-Care-Associated Pneumonia. Recommendations of CDC and the Healthcare Infection Control Practices Advisory Committee. p 57.

10. John Starmer, Dario Giuse (2008) A Real-time Ventilator Management Dashboard: Toward Hardwiring Compliance with Evidence-based Guidelines. AMIA 6: 702-706.

11. KoenPauwels, Tim Ambler, Bruce H Clark, Pat LaPointe, David Reibstein (2009) Dashboards as a Service Why, What, How and What Research Is Needed?. Journal of Service Research 12(2).

12.John W Bennett, Paul P Glasziou (2003) Computerised reminders and feedback in medication management: a systematic review of randomised controlled trials. Med J Aust 178(5): 217-222.

13. Dowding D, Randell R, Gardner P, Fitzpatrick G, Dykes P, et al. (2014) Dashboards for Improving Patient Care: Reviewof the Literature. International Journal of Medical Informatics 84(2): 87-100.

14. Sarah Calkin (2012) Nurse ratios to be published by trusts for first time.

15. Reza Shahpori, Noel Gibney, Nancy Guebert, Caroline Hatcher, David Zygun (2014) An on-line dashboard to facilitate monitoring of provincial ICU bed occupancy in Alberta, Canada. Journal of Hospital Administration 3(1).

16. Victor Zaydfudim, Lesly A Dossett, John M Starmer, Patrick G Arbogast, Irene D Feurer, et al. (2009) Implementation of a Real-time Compliance Dashboard to Help Reduce SICU Ventilator-Associated PneumoniaWith the Ventilator Bundle. Arch Surg 144(7): 657-658.

17. Debra J Hurd, Brian D Patty (2013) Innovation with Information Technologies in Healthcare $\left(1^{\text {st }} \mathrm{Edn}\right)$.

18. Heather L Evans, Elizabeth McNamara, John B Lynch, Jeannie D Chan, Mark Taylor (2012) Infection Control for Critically Ill Trauma Patients: A Systematic Approach to Prevention, Detection, and Provider Feedback. Critical Care Nursing Quarterly 35(3): 241-246. 
19. Marie Egan (2006) Clinical Dashboards Impact on Workflow, Care Quality and Patient Safety. Crit Care Nurs Q 29(4): 354-361.

20. Mazlom SR, Rajabpoor M (2014) Development and Assessment of
Computerized Software for Nursing Process: a Step toward Promotion of Nursing Education and Care. Iranian Journal of Medical Education 14(4): 312-322.

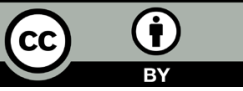

his work is licensed under Creative Commons Attribution 4.0 Licens DOI: 10.19080/IJOPRS.2017.01.555557

\section{Your next submission with Juniper Publishers} will reach you the below assets

- Quality Editorial service

- Swift Peer Review

- Reprints availability

- E-prints Service

- Manuscript Podcast for convenient understanding

- Global attainment for your research

- Manuscript accessibility in different formats

( Pdf, E-pub, Full Text, Audio)

- Unceasing customer service

Track the below URL for one-step submission https://juniperpublishers.com/online-submission.php 